FHWA/IN/JTRP-2000/23

Final Report

DETERMINATION OF PRACTICAL ESALS PER TRUCK VALUES ON INDIANA ROADS

Sedat Gulen

John Nagle

John Weaver

Victor Gallivan

December 2000 
Final Report

FHWA/IN/JTRP-2000/23

\title{
DETERMINATION OF PRACTICAL ESALS PER TRUCK VALUES ON INDIANA ROADS
}

\author{
by \\ Sedat Gulen \\ Pavement Research and Statistical Engineer \\ Division of Research \\ Indiana Department of Transportation \\ John Nagle \\ Safety/Congestion Mana gement Engineer \\ Program Development Division \\ Indiana Department of Transportation \\ John Weaver \\ Chief \\ Program Development Division \\ Indiana Department of Transportation \\ Victor Lee Gallivan \\ Pavement/Materials Engineer \\ Federal Highway Administration \\ Indiana Division \\ Joint Transportation Research Program \\ Project No. C-36-54EEE \\ File No. 3-3-57 \\ SPR-2331
}

The contents of this report reflect the views of the authors, who are responsible for the facts and accuracy of the data presented herein. The contents do not necessarily reflect the official views or policies of the Indiana Department of Transportation nor the Federal Highway Administration. This report does not constitute a standard, specification, or regulation.

INDOT Division of Research

West Lafayette, Indiana

December 2000 


\begin{tabular}{|c|c|c|c|c|c|}
\hline \multicolumn{6}{|c|}{ TECHNICAL REPORT STANDARD TITLE AGE } \\
\hline $\begin{array}{l}\text { 1. Report No. } \\
\text { FHWA/IN/JTRP-2000/23 }\end{array}$ & \multicolumn{3}{|c|}{ 2. Government Accession No. } & \multicolumn{2}{|c|}{ 3. Recipient's Catalog No } \\
\hline \multirow{2}{*}{\multicolumn{4}{|c|}{$\begin{array}{l}\text { 4. Title and Subtitle } \\
\text { Determination of Practical ESALs Per Truck Values on Indiana Roads }\end{array}$}} & \multicolumn{2}{|l|}{$\begin{array}{l}\text { 5. Report Date } \\
\text { December } 2000\end{array}$} \\
\hline & & & & \multicolumn{2}{|c|}{ 6. Performing Organization Code } \\
\hline \multicolumn{4}{|c|}{$\begin{array}{l}\text { 7. Author(s) } \\
\text { Sedat Gulen, John Nagle, John Weaver and Victor Lee Gallivan }\end{array}$} & \multicolumn{2}{|c|}{$\begin{array}{l}\text { 8. Performing Organization Report No. } \\
\text { FHWA/IN/JTRP-2000/23 }\end{array}$} \\
\hline \multirow{2}{*}{\multicolumn{4}{|c|}{$\begin{array}{l}\text { 9. Performing Organization Name and Address } \\
\text { Joint Transportation Research Program } \\
\text { Indiana Department of Transportation } \\
\text { Research Division } \\
\text { P.O. Box } 2279 \\
\text { West Lafayette, IN } 47906\end{array}$}} & \multicolumn{2}{|l|}{ 10. Work Unit No. } \\
\hline & & & & \multicolumn{2}{|c|}{$\begin{array}{r}\text { 11. Contract or Grant No. } \\
\text { SPR-2331 }\end{array}$} \\
\hline \multicolumn{4}{|c|}{$\begin{array}{l}\text { 12. Sponsoring Agency Name and Address } \\
\text { Indiana Department of Transportation } \\
\text { State Office Building } \\
100 \text { North senate Building } \\
\text { Indianapolis, In } 46204\end{array}$} & \multicolumn{2}{|c|}{$\begin{array}{l}\text { 13. Type of Report and Period Covered } \\
\text { Final Report }\end{array}$} \\
\hline \multicolumn{6}{|c|}{$\begin{array}{l}\text { 15. Supplementary Notes } \\
\text { Prepared in cooperation with the Indiana Department of Transportation and Federal Highway Administration }\end{array}$} \\
\hline \multicolumn{6}{|c|}{$\begin{array}{l}\text { 16. Abstract } \\
\text { The Indiana Department of Transportation (INDOT) has been using ESAL (Equivalent Single Axle Load) values for } \\
\text { pavement design. The current ESAL values were obtained in the late 1970. However, truck deregulation and higher } \\
\text { allowable maximum loads have increased the 1970's values. Updated ESAL values are needed for better road designs. } \\
\\
\text { The } 1998 \text { and } 1999 \text { traffic data from the all Weight-in-Motion (WIM) stations were obtained and used to compute updated } \\
\text { ESAL values for multiple unit trucks (Class } 9 / \text { F-9) and single unit trucks (Class } 5,6 \text { and 7). Statistical analyses indicated } \\
\text { that average ESAL values for } 1998 \text { and } 1999 \text { are statistically the same, but the average ESAL values for interstates roads and } \\
\text { non-interstates roads are not all statistically the same. Some WIM stations were deleted for definite calibration problems. } \\
\text { Due to other calibration deficiencies, the data was refined before final ESAL computations. Then the following ESAL values } \\
\text { were computed and recommended to be used for future INDOT road designs: }\end{array}$} \\
\hline \multicolumn{6}{|c|}{ For Multiple Unit Trucks (Class 9): } \\
\hline $\begin{array}{l}\text { a) } \\
\text { b) }\end{array}$ & \multicolumn{5}{|c|}{$\begin{array}{l}\text { 1.3 ESAL/Truck for flexible pavements } \\
\text { 2.0 ESAL/Truck for rigid pavements }\end{array}$} \\
\hline \multicolumn{6}{|c|}{ For Single Unit Trucks (Class 5, $6 \&$ 7): } \\
\hline $\begin{array}{l}\text { a) } \\
\text { b) }\end{array}$ & \multicolumn{5}{|c|}{$\begin{array}{l}\text { 0.6 ESAL/Truck for flexible pavements } \\
\text { 0.9 ESAL/Truck for rigid pavements }\end{array}$} \\
\hline $\begin{array}{l}\text { 17. Key Words } \\
\text { ESAL, Equivalent Single A } \\
\text { WIM }\end{array}$ & e Loads, & avement Design, & $\begin{array}{l}\text { 18. Distribution } \\
\text { N0 Restrictions. } \\
\text { through Nationa } \\
\text { VA } 22161\end{array}$ & $\begin{array}{l}\text { Statement } \\
\text { This document is availal } \\
\text { Technical Information } C\end{array}$ & $\begin{array}{l}\text { e to the public } \\
\text { nter, Springfield, }\end{array}$ \\
\hline $\begin{array}{l}\text { 19. Security Classif. (of tl } \\
\text { Unclassified }\end{array}$ & report) & $\begin{array}{r}\text { 20. Security Cl } \\
U\end{array}$ & $\begin{array}{l}\text { sif. (of this page) } \\
\text { lassified }\end{array}$ & $\begin{array}{l}\text { 21. No. of Pages } \\
28\end{array}$ & 22. Price \\
\hline
\end{tabular}




\section{TECHNICAL Summary}

INDOT Research

Technology Transfer and Project Implementation Information

TRB Subject Code: 24-01 Pavement Management Systems

Publication No.FHWA/IN/JTRP-2000/23, SPR-2331

December 2000

Final Report

\section{Practical Pavement Performance Prediction Models for Indiana Roads}

\section{Introduction}

The Indiana Department of Transportation (INDOT) uses equivalent single axle load (ESAL) values as part of the information needed for pavement design. The current ESAL values were last estimated in the late 1970s. However, truck deregulation and higher allowable maximum loads have led to increases in truck weights and axleloads on Indiana roads. This study investigated updating the ESAL values in order to validate current pavement design process.

There are currently thirty-six WIM Stations, twenty-six of them on Interstate Roads and the

\section{Findings}

The following conclusions and recommendations were based on this research study using 1998 and 1999 traffic data:

1. The updated ESAL values computed for Single Unit and Multiple Unit Trucks, are higher than those used currently.

2. The average ESAL values on Interstates roads are statistically higher than on NonInterstates roads.

3. Even though the average ESAL values for Interstates and Non-Interstates roads are not statistically the same, for all practical purposes the following overall ESAL values per truck are recommended to be used for future road pavement mix designs in Indiana are: remaining are on the other INDOT roads. The 1998 and 1999 traffic data from the all Weigh-inMotion (WIM) stations were obtained and an average ESAL value per lane per day was computed for multiple unit trucks (Class 9/F-9) and single unit trucks (Class 5, 6 and 7) as a group. Some WIM stations were deleted because of calibration problems. Due to other calibration deficiencies, the data was further refined before final ESAL computations were made.
For Multiple Unit Trucks (class 9):

$\mathbf{1 . 3}$ for flexible pavements

2.0 for rigid pavements

For Single Unit Trucks (Class 5, Class 6 and Class 7):

0.6 for flexible pavements

0.9 for rigid pavements

4. The distribution of the ESALs and gross weights of trucks was found to be approximately normally distributed.

5. The accuracy of the ESAL values is dependent upon the accuracy of the WIM stations. It is recommended that the calibrations of the WIM stations use class 9 trucks. 


\section{Implementation}

The research results were presented to the pavement design committee and they have already implemented the new ESAL estimates into their design of pavements.

\section{Contact}

For more information:

\author{
John Weaver/John Nagle \\ Principal Investigators \\ Indiana Department of Transportation \\ Roadway Management Division. \\ State Office Building Room: N808 \\ 100 N. Senate Avenue. \\ Indianapolis, IN 46204 \\ Phone: 317-232-5884 \\ Fax: (317) 232-5478

\section{Sedat Gulen} \\ Principal Investigator \\ Indiana Department of Transportation \\ Research Division \\ 1205 Montgomery Road \\ P.O.Box 2279 \\ West Lafayette, IN 47906 \\ Phone: (765) 463-1521 \\ Fax: (765) 497-1665
}

This research has led to more valid pavement designs for today's traffic of heavier and increased numbers of commercial vehicles.
Indiana Department of Transportation

Division of Research

1205 Montgomery Street

P.O. Box 2279

West Lafayette, IN 47906

Phone: (765) 463-1521

Fax: (765) 497-1665

Purdue University

Joint Transportation Research Program

School of Civil Engineering

West Lafayette, IN 47907-1284

Phone: (765) 494-9310

Fax: (765) 496-1105 


\section{ACKNOWLEDGMENTS}

This report was prepared by Sedat Gulen, John Nagle, John Weaver for the Indiana Department of Transportation and Lee Gallivan for the Federal Highway Administration, Indiana Division. The authors wish to thank Mr. Gordon Hooker, Research Division, who reduced the raw data and prepared various plots for this research. The authors would also thank to Geraldine Lampley, Program Development Division, who supplied the original raw data. 


\section{INTRODUCTION:}

Indiana Department of Transportation (INDOT) has been increasingly using the average ESAL (Equivalent Single Axle Load) per truck for pavement design. The current ESAL values per multiple-unit truck and single-unit truck were prepared and validated in the late 1970's, Table 1, Chapter 52, INDOT Design Manual ${ }^{(1)}$. Truck deregulation and higher allowable maximum loads have affected these 1970's values. For this reason more realistic and reasonable ESAL estimates are now required on the title sheets of plans for design of pavements in Indiana and the results of this study will also improve ESAL/Truck factors for estimating design ESALs.

INDOT has thirty six weigh-in-motion (WIM) sites total. Thirty-two WIM sites were constructed in 1992-93 in conjunction with the Long Term Pavement Performance (LTPP) efforts. An additional site was constructed to monitor a research project in 1993 and three sites were installed for monitoring of pavement warranty projects. The sites used International Road Dynamics® Inc. bending plates, on site data collector and software. Many of the bending plates and load cells have now been replaced by piezo weight sensors. Each location is calibrated once a year by maintenance agreement and after a major repair to the site. Sites were calibrated using a class 7 vehicle of a known weight of $22.7 \mathrm{Mg}$ (50,000 lbs.).

\section{OBJECTIVE:}

The objective of this research study is to update the average ESAL estimate values for multiple unit trucks (F-9) and single unit trucks (F-5, F-6 and F-7), Table 2, for use in pavement design procedures. 


\section{DATA COLLECTION}

The data were obtained from all installed WIM stations. There are currently thirty six WIM stations, twenty six of them on Interstate Roads and the remaining are on the other INDOT roads as shown on Table 3 and Table 4. In order to represent the most recent ESAL values, the 1998 and 1999 data collected by the WIM stations were compiled.

The average daily ESAL data for the single unit trucks and multiple unit trucks were calculated using AASHTO formulas and compiled from the WIM axle distributions. Due to calibration problems and breakdown of some WIM stations the ESAL data were refined by deleting data from the following categories.
a. If Class 9 truck (F-9) Gross Vehicle Weight (GVW) is equal to zero
b. If ESAL for F-9 is less than or equal 0.04
c. If GVW for Class 9 truck is less than $13.5 \mathrm{Mg}(30,000 \mathrm{lbs}$.)
d. If GVW for Class 9 truck is greater than $56.6 \mathrm{Mg}(125,000 \mathrm{lbs}$.)
e. If Class 7 truck GVW is equal to zero or greater than $30.8 \mathrm{Mg}(68,000 \mathrm{lbs}$.)
f. If Class 6 truck GVW is equal to zero or greater than $23.6 \mathrm{Mg}(52,000 \mathrm{lbs}$.)
g. If Class 5 truck $\mathrm{GVW}$ is equal to zero or greater than $17.2 \mathrm{Mg}(38,000 \mathrm{lbs}$.) 


\section{DATA ANALYSES}

Looking at the distribution of classes of trucks it was observed that the five-axle semi (class 9) trucks typically made up $80 \%$ of the volumes of all trucks and over $85 \%$ of all calculated ESALs. Therefore Class 9's were used for the data analysis to simplify the calculations. An average ESAL per truck was also determined for Class 5, 6 and 7's as a group since the pavement design calculations asked for one. The distribution of daily average ESAL values and daily average gross vehicle weights were checked and found to be approximately normally distributed for each WIM station and the variances were also found to be homogeneous, Figures 1-6. The ESAL values used in the statistical analyses were computed for flexible pavement with terminal PSI=2.5 and Structural Number=5. The Analysis of Variances (ANOVA) ${ }^{(2)}$ and other statistical techniques were utilized to analyze the ESAL data by using the SAS ${ }^{(3)}$ Institute Statistical Package Version 8.00.

ANOVA indicated that:

1. The average ESAL values, for class 9 trucks, of individual WIM stations are all not statistically the same.

2. The effect of the year on average ESAL values is not statistically significant.

3. The average ESAL values of the WIM stations on Interstates Roads are statistically higher than on Non-Interstates Roads, Table 5 and Table 6.

Since average ESAL values are statistically different for individual WIM stations on Interstates and Non-Interstates roads, various average ESAL values for Class 9, Class 5, Class 6 and Class 7 trucks were computed. Tables 7 and 8 show average ESAL values of Class 5, 6, 7, and 9 trucks. Tables 7 and 8 also show standard deviation, number of lane days (observations), average (AVG) total number of trucks, total traffic, and percent of Class 9 trucks by years and WIM Stations. 
Table 7 and 8 shows, for example, for WIM site 4110, in 1998, the average ESAL per class 9 trucks is 2.0. The average GVW was $28.3 \mathrm{Mg}(62,199 \mathrm{lbs}$.) with 353 lane days of observations.

Table 9 shows overall average ESAL values, number of lane days and standard deviations for Class 5, 6 and 7 trucks on all roads combined. The weighted ESAL value for Single Unit Trucks was then computed from Table 9 and found to be 0.6 ESAL/Truck.

Table 10 shows overall average ESAL values, number of lane days, GVW in pounds, total truck count, total traffic count and percent of Class 9 Trucks. The weighted average ESAL Class 9 Trucks was then computed as 1.3 ESAL/Truck.

Updated ESAL values for Single Unit and Multiple Unit Trucks are then computed and listed in Table 11. Table 11 also shows the effect of varying the terminal PSI from the department standard value of 2.5 to 2.0 PSI. This demonstrates the nominal effect of varying the terminal serviceability on the ESAL calculation. 


\section{CONCLUSIONS AND RECOMMENDATIONS}

The following conclusions and recommendations were based on this research study using 1998 and 1999 traffic data:

1. The updated ESAL values computed for Single Unit and Multiple Unit Trucks, Table 6, are higher than those used currently.

2. The average ESAL values on Interstate roads are statistically higher than on Non-Interstate roads.

3. Even though the average ESAL values for Interstates and Non-Interstates roads are not statistically the same, for all practical purposes the following overall ESAL values per truck are recommended to be used for future road pavement mix designs in Indiana.

For Multiple Unit Trucks (class 9):

- $\quad$ 1.3 ESAL/Truck for flexible pavements

- 2.0 ESAL/Truck for rigid pavements

For Single Unit Trucks (Class 5, Class 6 and Class 7):

- 0.6 ESAL/Truck for flexible pavements

- $\quad$ 0.9 ESAL/Truck for rigid pavements

4. The distribution of the ESAL and the GVW of trucks was found to be approximately normally distributed.

5. The accuracy of the ESAL values is dependent upon the accuracy of the WIM stations. It is recommended that the calibrations of the WIM stations use class 9 trucks. 


\section{REFERENCES}

1. INDOT, Chapter 52, Pavement Design Manual.

2. Anderson V. L. and McLean R. A., Design of Experiments Realistic Approaches, Mercel Decker Inc., New York N. Y.

3. SAS Publications on Statistics and Linear Models, SAS Institute Inc., Cary. NC. 


\section{LIST OF TABLES}

Table

Table 1

The current ESAL Values for INDOT

Table 2. Class 5, Class 6, Class 7 and Class 9 Trucks

Table 3 Indiana Weigh-in-Motion (WIM)

Table $4 \quad$ Listing of WIM Stations

Table 5. Duncan's Comparison of Means Tests for ESAL9 Values

Table 6. Average ESAL for Interstates and Non-Interstates Roads

Table 7 Average ESAL Values of WIM stations by years

Table 8 Average ESAL Values of WIM stations by years (continuation of Table 7)

Table 9 Overall Average ESAL Values for Class 5, 6, and 7 Trucks

Table 10 Overall Average ESAL Values for Class 9 Trucks

Table $11 \quad$ Updated ESAL

\section{Page}

9

10

11

12

13

14

15

16

17

18

19 


\section{LIST OF FIGURES}

Figures Description Page

Figure 1 WIM Station 4110, I-65, July 1999, ESAL9 vs. PERCENT 20

Figure 2 WIM Station 4250, SR-2, May 1999, ESAL9 vs. PERCENT 21

Figure 3 WIM Station 5110, I-70, May 1999, ESAL9 vs. PERCENT 22

Figure 4 WIM Station 4110, I-65, May 1999, WEIGHT vs. PERCENT 23

Figure 5 WIM Station 4250, SR-2, Jun 1999, WEIGHT vs. PERCENT 24

Figure 6 WIM Station 5110, I-70, Jun 1999, WEIGHT vs. PERCENT 25 
Table 1. The current ESAL Values for INDOT

\begin{tabular}{|c|c|c|}
\hline Pavement Type & Single Unit Trucks & Multiple Unit Trucks \\
\hline Flexible & 0.316 & 0.860 \\
\hline Rigid & 0.230 & 1.115 \\
\hline
\end{tabular}


Table 2. Class 5 (F-5), Class 6 (F-6), Class 7 (F-7) and Class 9 (F-9) Trucks.

\section{Classification \#5 Two-Axle, Six-Tire Single Unit Truck (SU): All vehicles on a single frame including camping and recreational vehicles, motor homes, large step vans, etc. having 2 Axles and Dual Rear Tires.}
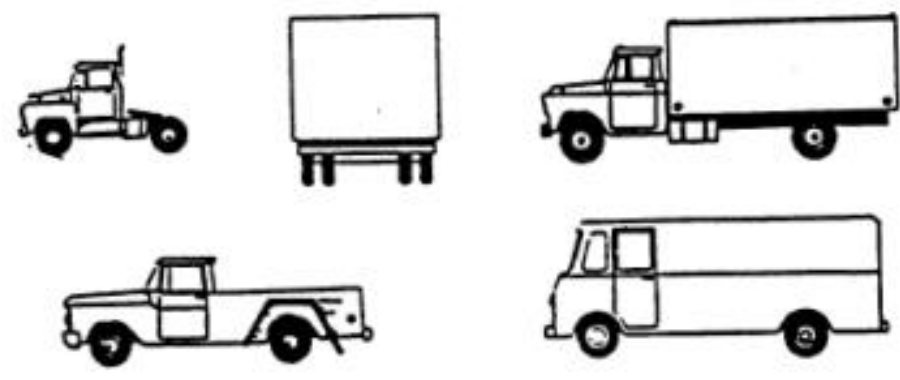

\section{Classification \#6}

Three-Axle Single Unit Truck (SU): All vehicles on a single frame having three axles.
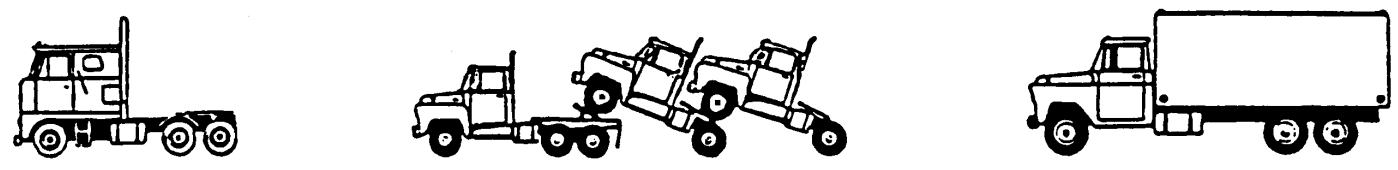

\section{Classification \#7 Four or More Axle Single Unit Truck (SU): All vehicles on a single frame having four or more axles.}
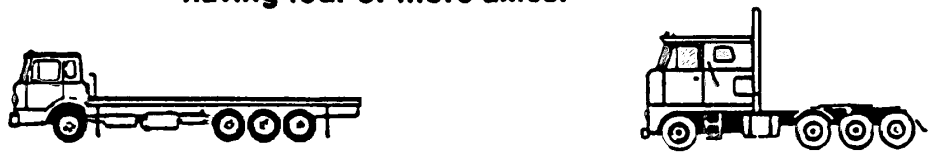

\section{Classification \#9 Five-Axle Single Traller Truck (Combo): All vehicles consisting of two unlis, of which the pulling unit is a tractor or single unit truck.}
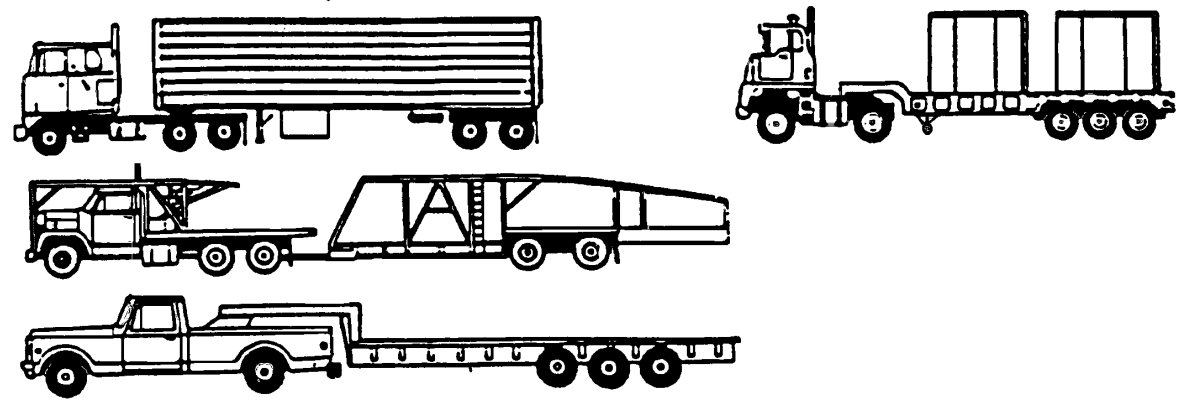

Note: Figures were taken from “Operation Tips Trafi COMP® III”, Model 241 operating manual, as modified by INDOT. 
Table 3.

INDI ANA

LEGEO

- Pavement warranty siles

- Pavenent researct site

- Part-af-Eniry sites

- LTPP/SHPP sies

- OTHER STES

\section{Weigh-in-Motion [WIM]}
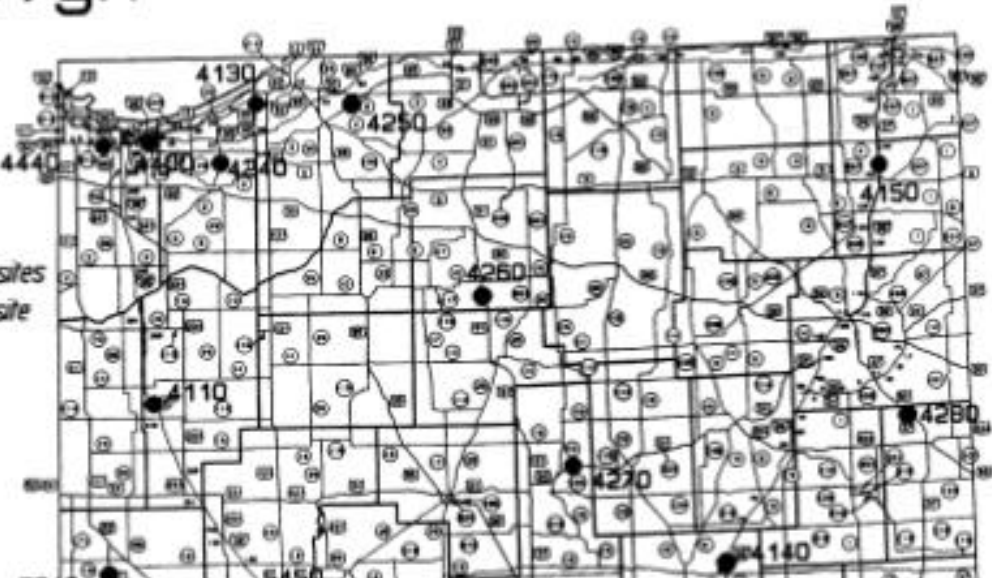

$$
5240
$$
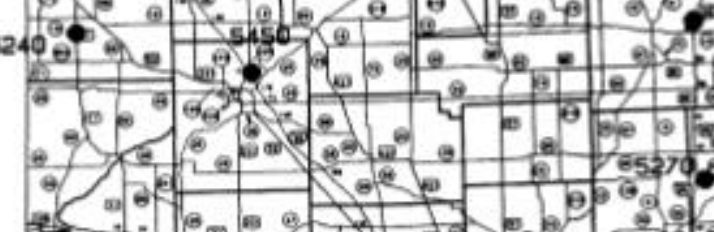

$8 e^{2}$

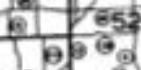

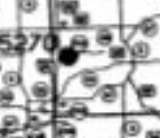
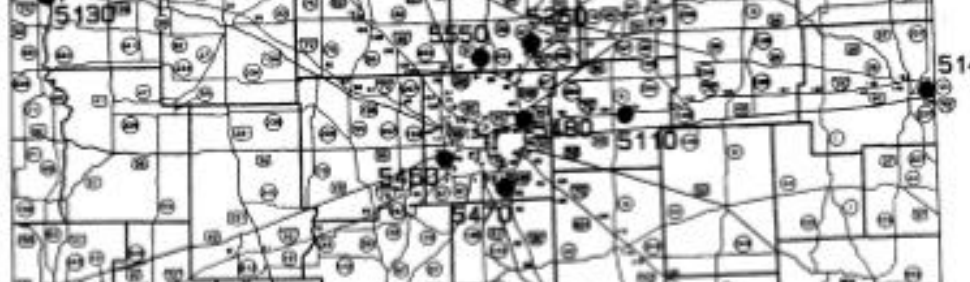

(e) 9
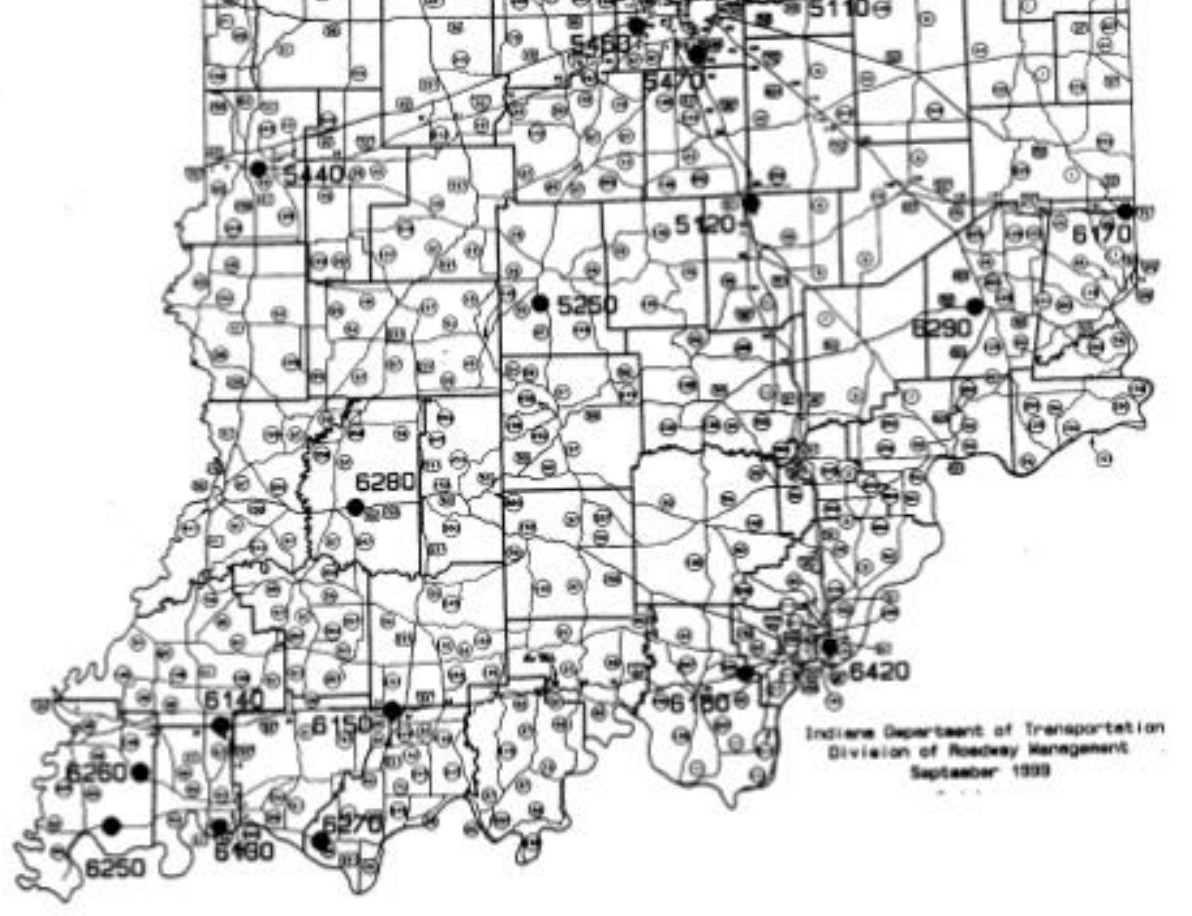
Table 4. Listing of WIM Stations

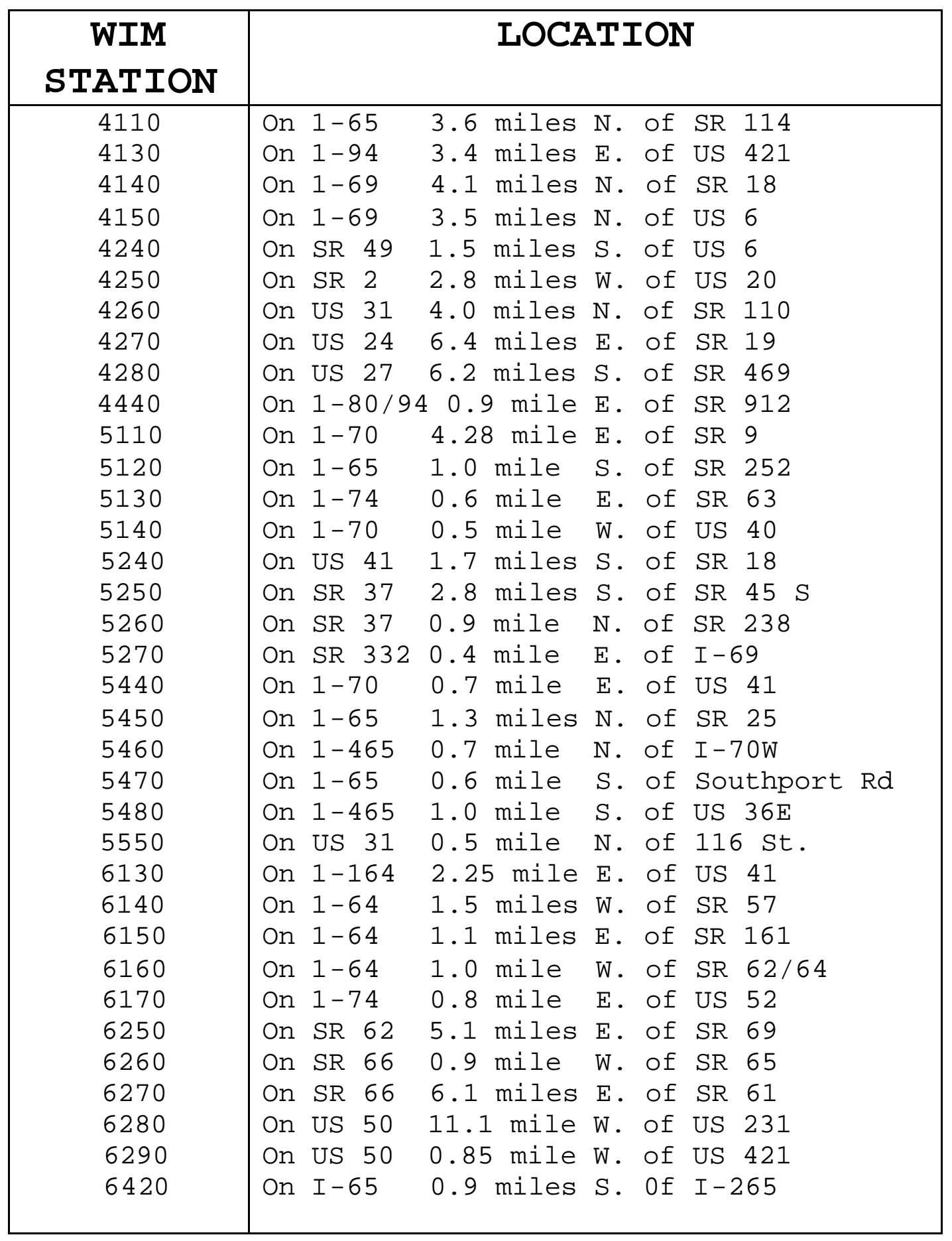




\section{Table 5. Duncan's Multiple Range Test for ESAL9}

NOTE: This test controls the Type I comparisonwise error rate, not the experimentwise error rate.

$\begin{array}{ll}\text { Alpha } & 0.05 \\ \text { Error Degrees of Freedom } & 31504 \\ \text { Error Mean Square } & 2.425866 \\ \text { Harmonic Mean of Cell Sizes } & 12356.52\end{array}$

Number of Means

2

Critical Range

0.03884

$\begin{array}{clll}\text { Duncan Grouping } & \underline{\text { Mean }} & \underline{\mathbf{N}} & \underline{\text { Roads }} \\ \mathrm{A} & 1.37490 & 23070 & \text { INTERSTATES } \\ \mathrm{B} & 1.23984 & 8438 & \text { NON-INTERSTATES }\end{array}$

Means with the same letter under "Duncan Grouping" are not significantly different. Means with the different letter under "Duncan Grouping" are significantly different.

NOTE: Cell sizes are not equal.

Where:

$$
\begin{aligned}
& \mathrm{N} \text { = Number of Observations (lane-days) } \\
& \text { Mean = Average ESAL/Truck value }
\end{aligned}
$$




\section{Table 6. Average ESAL Values of Interstates (INT) and Non-Interstates (NINT) Roads}

\begin{tabular}{|c|c|c|c|c|c|c|c|c|c|c|c|}
\hline ROADS & YEAR & $\begin{array}{r}\text { AVG. } \\
\text { ESAL5 }\end{array}$ & $\begin{array}{l}\text { AVG. } \\
\text { ESAL6 }\end{array}$ & $\begin{array}{r}\text { AVG. } \\
\text { ESAL } 7\end{array}$ & $\begin{array}{r}\text { AVG. } \\
\text { ESAL } 9\end{array}$ & s9 & N9 & AVWGHT 9 & TOTAL_F9 & T_ADT & PRCT_F9 \\
\hline INT & 98 & 0.14 & 0.41 & 1.73 & 1.18 & 1.28 & 11339 & 54246 & 17799644 & 119347130 & 15 \\
\hline INT & 99 & 0.19 & 0.70 & 1.84 & 1.54 & 2.08 & 12143 & 55808 & 18453701 & 142830973 & 13 \\
\hline NINT & 98 & 0.19 & 0.63 & 2.63 & 1.26 & 0.75 & 4176 & 53744 & 1127922 & 18034400 & 6 \\
\hline NINT & 99 & 0.18 & 0.60 & 2.23 & 1.22 & 0.87 & 4262 & 52497 & 901638 & 18522540 & 5 \\
\hline
\end{tabular}

Where:

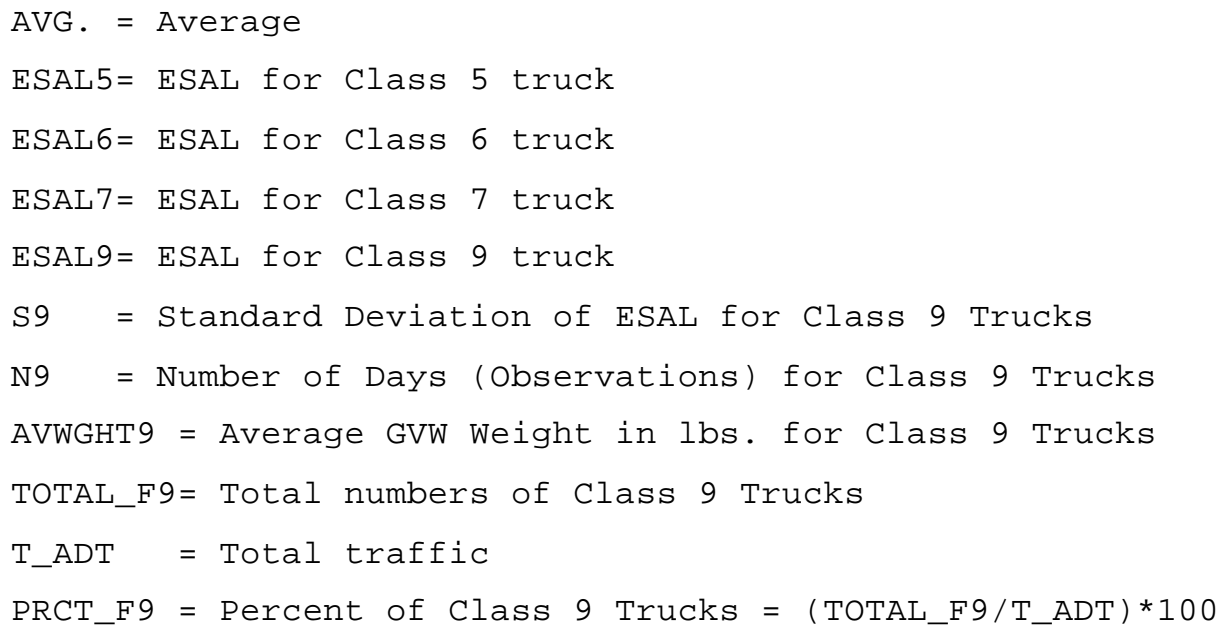


Table 7. Average ESAL values of WIM Stations by years

\begin{tabular}{|c|c|c|c|c|c|c|c|c|c|c|c|}
\hline SITE & YEAR & $\begin{array}{l}\text { AVG. } \\
\text { ESAL5 }\end{array}$ & $\begin{array}{l}\text { AVG. } \\
\text { ESAL } 6\end{array}$ & $\begin{array}{l}\text { AVG. } \\
\text { ESAL } 7\end{array}$ & $\begin{array}{l}\text { AVG. } \\
\text { ESAL } 9\end{array}$ & s9 & N9 & AVWGHT 9 & TOTAL_F9 & T_ADT & PRCT_F9 \\
\hline 4110 & 98 & 0.24 & 0.59 & 2.14 & 2.00 & 1.98 & 353 & 62199 & 1041126 & 3500713 & 30 \\
\hline 4110 & 99 & 0.28 & 0.55 & 2.03 & 1.36 & 1.36 & 357 & 57219 & 972011 & 3648949 & 27 \\
\hline 4130 & 98 & 0.08 & 0.37 & 0.99 & 0.95 & 0.48 & 157 & 55008 & 192267 & 1181379 & 16 \\
\hline 4130 & 99 & 0.07 & 0.74 & 1.08 & 1.54 & 2.28 & 1539 & 57090 & 1681399 & 12264426 & 14 \\
\hline 4140 & 98 & 0.43 & 0.56 & 1.19 & 3.17 & 1.83 & 128 & 66444 & 262257 & 1086691 & 24 \\
\hline 4140 & 99 & 0.08 & 0.16 & 0.72 & 0.35 & 0.19 & 236 & 37793 & 556860 & 2287585 & 24 \\
\hline 4150 & 98 & 0.06 & 0.36 & 1.96 & 0.88 & 0.24 & 1227 & 53999 & 1041762 & 8102358 & 13 \\
\hline 4150 & 99 & 0.07 & 0.30 & 1.46 & 0.68 & 0.71 & 1021 & 47851 & 918608 & 6699807 & 14 \\
\hline 4250 & 98 & 0.15 & 0.52 & 2.01 & 0.81 & 0.45 & 335 & 49447 & 29244 & 1298348 & 2 \\
\hline 4250 & 99 & 0.16 & 0.61 & 3.28 & 0.82 & 0.25 & 418 & 51429 & 46544 & 1586597 & 3 \\
\hline 4260 & 98 & 0.14 & 0.26 & 1.69 & 0.78 & 0.57 & 350 & 46725 & 209000 & 1820541 & 11 \\
\hline 4260 & 99 & 0.19 & 0.21 & 1.06 & 1.46 & 0.86 & 318 & 49261 & 105517 & 1733455 & 6 \\
\hline 4270 & 98 & 0.10 & 0.45 & 2.04 & 1.04 & 0.63 & 578 & 55051 & 200041 & 2094049 & 10 \\
\hline 4270 & 99 & 0.06 & 0.24 & 1.37 & 0.60 & 0.18 & 706 & 48275 & 248067 & 2536184 & 10 \\
\hline 4440 & 98 & 0.08 & 0.13 & 0.77 & 0.79 & 0.74 & 367 & 46074 & 1179152 & 7427882 & 16 \\
\hline 4440 & 99 & 0.11 & 0.37 & 1.36 & 0.94 & 0.72 & 35 & 49885 & 40331 & 2041203 & 2 \\
\hline 5110 & 98 & 0.10 & 0.36 & 1.31 & 1.36 & 1.02 & 1366 & 57369 & 2880747 & 10676272 & 27 \\
\hline 5110 & 99 & 0.19 & 0.51 & 1.37 & 1.42 & 1.12 & 736 & 58806 & 1331715 & 6327112 & 21 \\
\hline 5120 & 98 & 0.09 & 0.28 & 1.68 & 0.75 & 0.29 & 1001 & 51559 & 1131723 & 8505395 & 13 \\
\hline 5120 & 99 & 0.10 & 0.29 & 1.19 & 0.94 & 1.40 & 984 & 51432 & 1809567 & 10334443 & 18 \\
\hline 5130 & 98 & 0.07 & 0.36 & 0.65 & 0.95 & 0.89 & 479 & 49275 & 391844 & 3072107 & 13 \\
\hline 5130 & 99 & 0.04 & 0.30 & 0.67 & 0.68 & 1.03 & 378 & 46426 & 524354 & 2306624 & 23 \\
\hline 5140 & 98 & 0.15 & 0.37 & 1.37 & 1.05 & 1.00 & 676 & 51522 & 1247071 & 8340708 & 15 \\
\hline 5140 & 99 & 0.20 & 0.55 & 1.25 & 1.57 & 0.70 & 633 & 60667 & 1930699 & 7200285 & 27 \\
\hline 5240 & 98 & 0.29 & 0.50 & 2.04 & 1.30 & 0.32 & 312 & 59802 & 150421 & 572047 & 26 \\
\hline 5240 & 99 & 0.62 & 0.54 & 3.13 & 1.44 & 0.49 & 92 & 59988 & 36031 & 144630 & 25 \\
\hline 5250 & 98 & 0.16 & 0.69 & 2.36 & 0.96 & 0.23 & 320 & 51154 & 94530 & 2025888 & 5 \\
\hline 5250 & 99 & 0.16 & 0.35 & 1.18 & 0.54 & 0.23 & 346 & 42111 & 80757 & 2200297 & 4 \\
\hline 5260 & 98 & 0.34 & 1.51 & 4.36 & 1.89 & 0.60 & 341 & 59124 & 76156 & 2515952 & 3 \\
\hline 5260 & 99 & 0.25 & 1.90 & 4.28 & 1.72 & 0.68 & 347 & 57610 & 74401 & 2496548 & 3 \\
\hline 5270 & 98 & 0.05 & 0.35 & 2.14 & 0.60 & 0.21 & 287 & 47781 & 16709 & 1405305 & 1 \\
\hline 5270 & 99 & 0.06 & 0.49 & 2.69 & 0.88 & 0.51 & 396 & 50998 & 26104 & 2080380 & 1 \\
\hline 5440 & 98 & 0.12 & 0.26 & 0.80 & 0.76 & 0.43 & 595 & 50980 & 1536115 & 6694978 & 23 \\
\hline 5440 & 99 & 0.08 & 0.64 & 1.79 & 1.14 & 0.85 & 408 & 53513 & 1094240 & 4931142 & 22 \\
\hline 5450 & 98 & 0.09 & 0.33 & 1.69 & 1.08 & 0.96 & 710 & 51704 & 1952674 & 8966121 & 22 \\
\hline 5450 & 99 & 0.08 & 0.27 & 1.28 & 0.92 & 0.74 & 648 & 51154 & 2300703 & 8415835 & 27 \\
\hline 5460 & 98 & 0.15 & 0.35 & 1.95 & 1.17 & 0.72 & 1051 & 56422 & 1383317 & 18412506 & 8 \\
\hline 5460 & 99 & 0.18 & 0.41 & 1.61 & 1.09 & 1.30 & 947 & 55748 & 1209219 & 17075652 & 7 \\
\hline 5480 & 98 & 0.17 & 2.75 & 7.02 & 5.07 & 4.48 & 247 & 77352 & 361266 & 6558648 & 6 \\
\hline 5480 & 99 & 0.55 & 2.81 & 5.33 & 5.21 & 3.96 & 994 & 76829 & 1158894 & 27129442 & 4 \\
\hline 5550 & 98 & 0.14 & 0.47 & 1.64 & 0.93 & 0.18 & 15 & 53294 & 3885 & 149346 & 3 \\
\hline 5550 & 99 & 0.16 & 0.41 & 1.05 & 0.93 & 1.22 & 218 & 51835 & 75486 & 2296784 & 3 \\
\hline
\end{tabular}


Table 8. Average ESAL values of WIM Stations by years (continuation of Table 7)

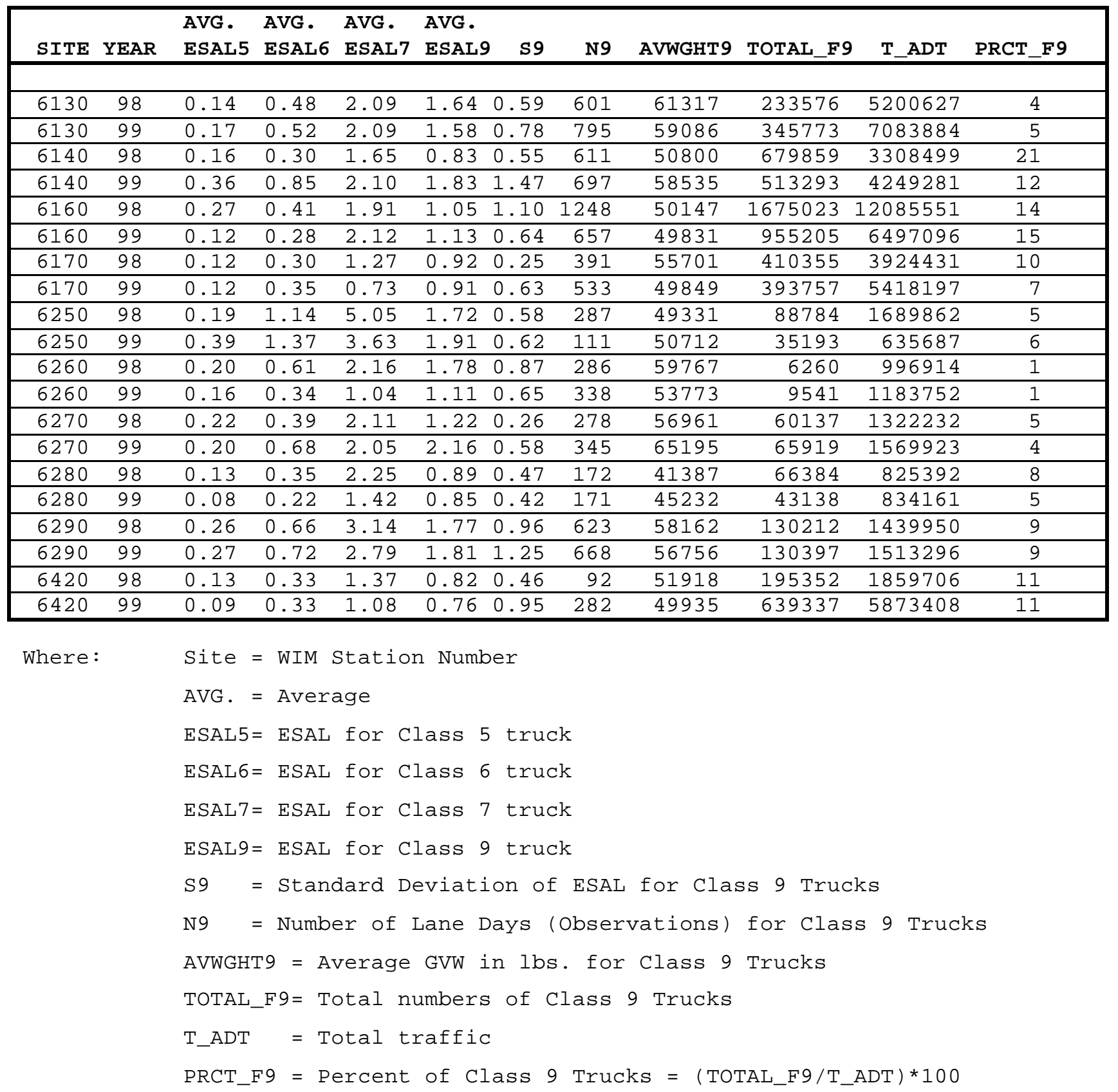

Note: $\mathrm{Mg}=1000 \mathrm{Kg}=2.2075 \mathrm{Kips}=2207.5 \mathrm{lbs}$.

lbs. $=1 / 2207.5 \mathrm{Mg}$ 
Table 9. Overall Average ESAL Values for Class 5, 6 and 7 Trucks by years

\begin{tabular}{|c|c|c|c|c|c|c|c|c|c|}
\hline YEAR & $\begin{array}{l}\text { AVG. } \\
\text { ESAL } 5\end{array}$ & S5 & N5 & $\begin{array}{l}\text { AVG. } \\
\text { ESAL } 6\end{array}$ & s6 & N6 & $\begin{array}{l}\text { AVG. } \\
\text { ESAL } 7\end{array}$ & S7 & N7 \\
\hline 98 & 0.15 & 0.41 & 9318 & 0.36 & 0.41 & 9329 & 1.3 & 0.91 & 9243 \\
\hline 99 & 0.16 & 0.29 & 10702 & 0.44 & 0.54 & 10864 & 1.2 & 0.99 & 10792 \\
\hline
\end{tabular}

$$
\text { Weighted } E S A L=\frac{0.15 * 9318+0.36 * 9329+1.3 * 9243+0.16 * 10702+0.44 * 10864+1.2 * 10792}{9318+10702+9329+10864+9243+10792}=0.6
$$

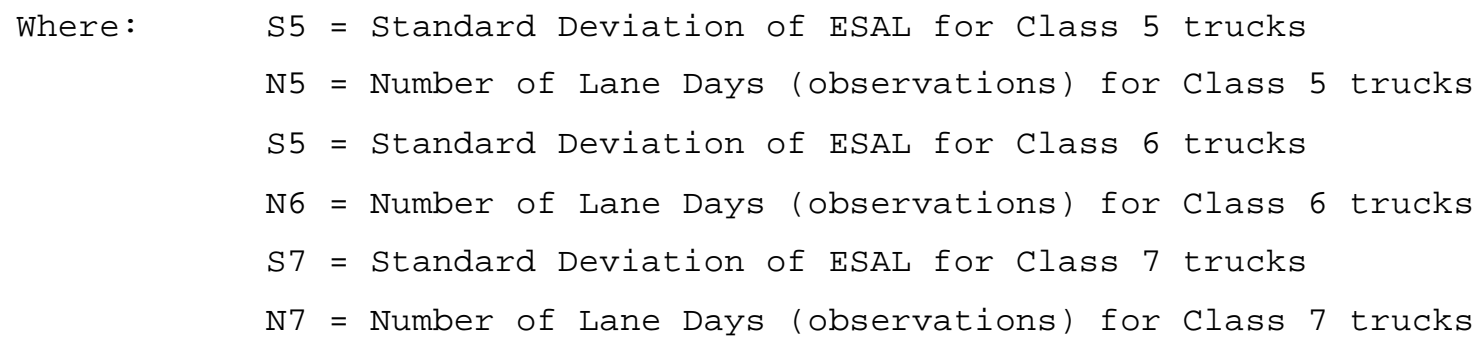


Table 10. Overall average ESAL values for Class 9 Trucks by Years

\begin{tabular}{|cccccccc|}
\hline YEAR & $\begin{array}{l}\text { AVG. } \\
\text { ESAL9 }\end{array}$ & S9 & N9 & AVWGHT9 & TOTAL_F9 & T_ADT & PRCT_F9 \\
\hline 1998 & 1.21 & 1.16 & 15117 & 54318 & 17748097 & 129632516 & 14 \\
\hline 1999 & 1.44 & 1.81 & 16319 & 54904 & 19312729 & 158554862 & 12 \\
\hline
\end{tabular}

$$
\text { Weighted } E S A L=\frac{1.21 * 15117+1.44 * 16319}{15117+16319}=1.32
$$

Note: The terms in the column heads are defined before. 
Table 11. Updated ESAL Values

\begin{tabular}{||c|c|c|c|c|c||}
\hline $\begin{array}{c}\text { PAVEMENT } \\
\text { TYPE }\end{array}$ & SN & $\begin{array}{c}\text { TERMINAL } \\
\text { PSI }\end{array}$ & $\begin{array}{c}\text { DEPTH } \\
\text { in }\end{array}$ & $\begin{array}{c}\text { SINGLE UNIT } \\
\text { CLASS 5-7 }\end{array}$ & $\begin{array}{c}\text { MULTIPLE } \\
\text { UNIT } \\
\text { CLASS 9 }\end{array}$ \\
\hline Flexible & 5 & 2.5 & - & 0.6 & 1.3 \\
\hline Flexible & 5 & 2.0 & - & $\begin{array}{c}0.98^{*} 0.8= \\
0.59\end{array}$ & $\begin{array}{c}1.3^{*} 0.98= \\
1.27\end{array}$ \\
\hline \multicolumn{1}{||l|}{} & & 10 & $\begin{array}{c}0.6^{*} 1.57= \\
0.9\end{array}$ & $\begin{array}{c}1.3^{*} 1.57= \\
2.0\end{array}$ \\
\hline Rigid & - & 2.5 & & $\begin{array}{c}0.98^{*} 1.2= \\
0.89\end{array}$ & $\begin{array}{c}0.98^{*} 2.0= \\
1.96\end{array}$ \\
\hline Rigid & - & 2.0 & 10 & &
\end{tabular}

Where: $\quad \mathrm{SN}=$ Structural Number

PSI $=$ Pavement Serviceability Index 
Figure 1. WIM Station 4110, on I-65, September 1999, North Bound Travel lane

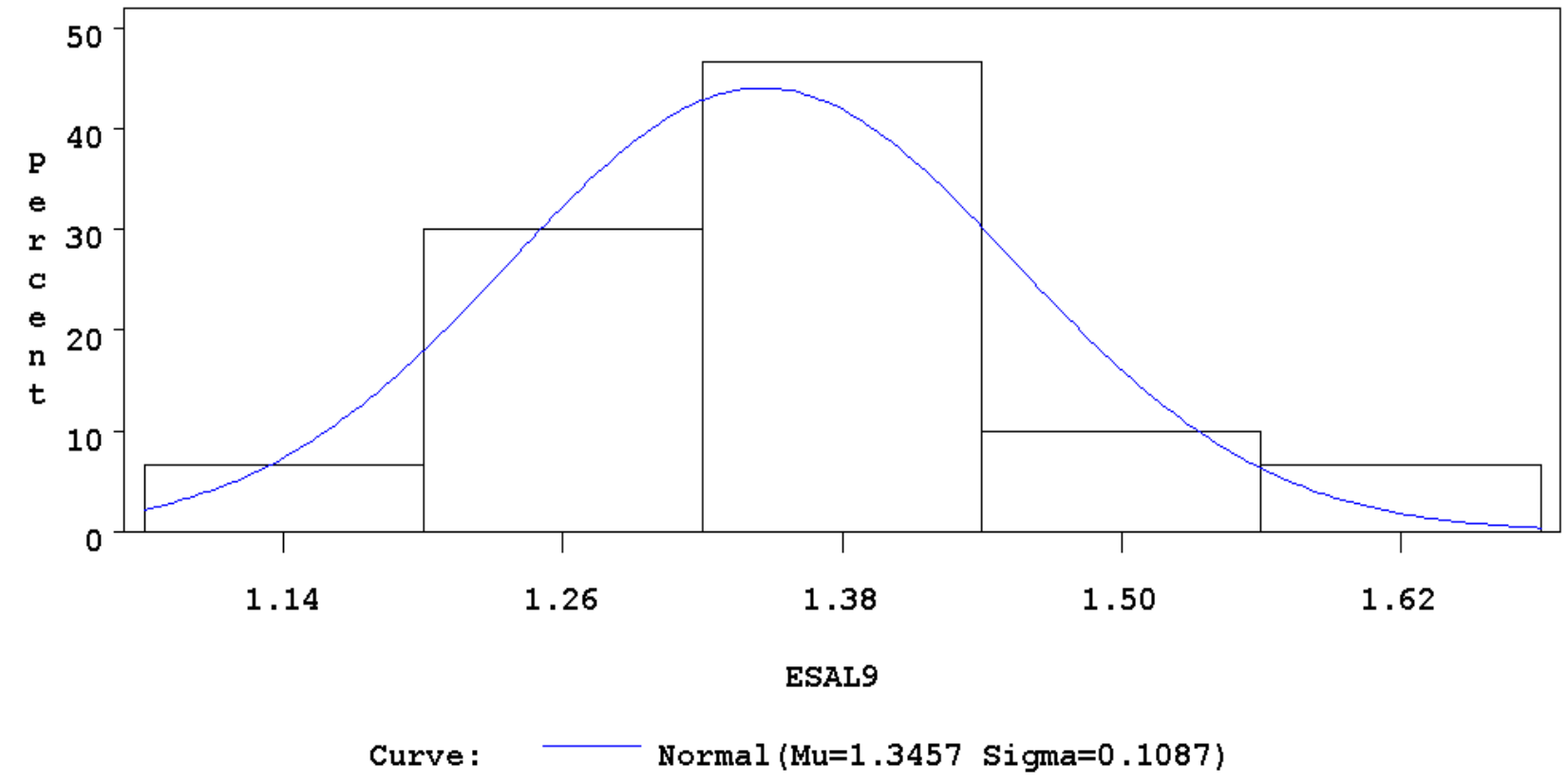

Where:

ESAL9= ESAL for Class $9(\mathrm{~F}-9)$ truck

$\mathrm{Mu}=$ Mean ESAL/Truck

Sigma $=$ Standard Deviation 
Figure 2. WIM Station 4250, on SR-2, May 1999, South Bound travel Lane

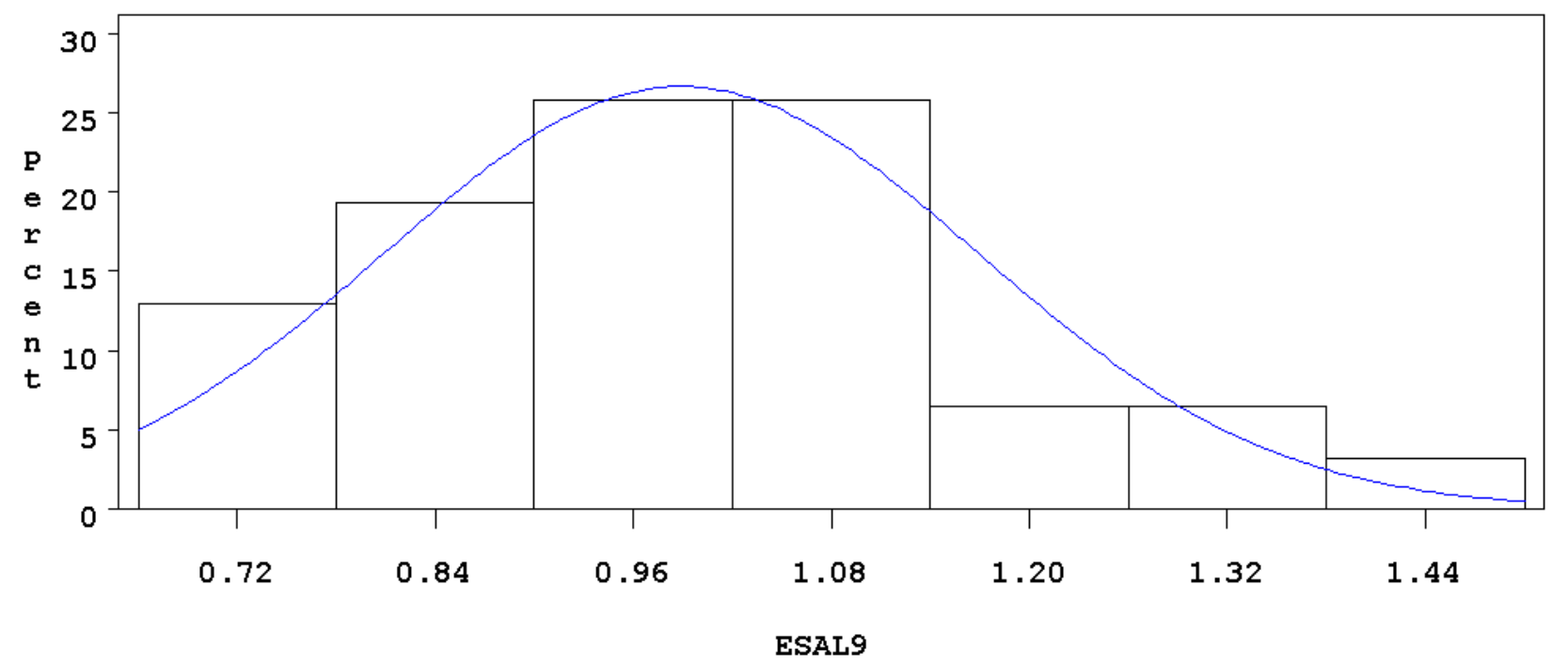

Curve: $\quad$ Normal (Mu=0.989 Sigma=0.1796) 
Figure 3. WIM station 5110, on I-70, May 1999, East Bound Travel Lane

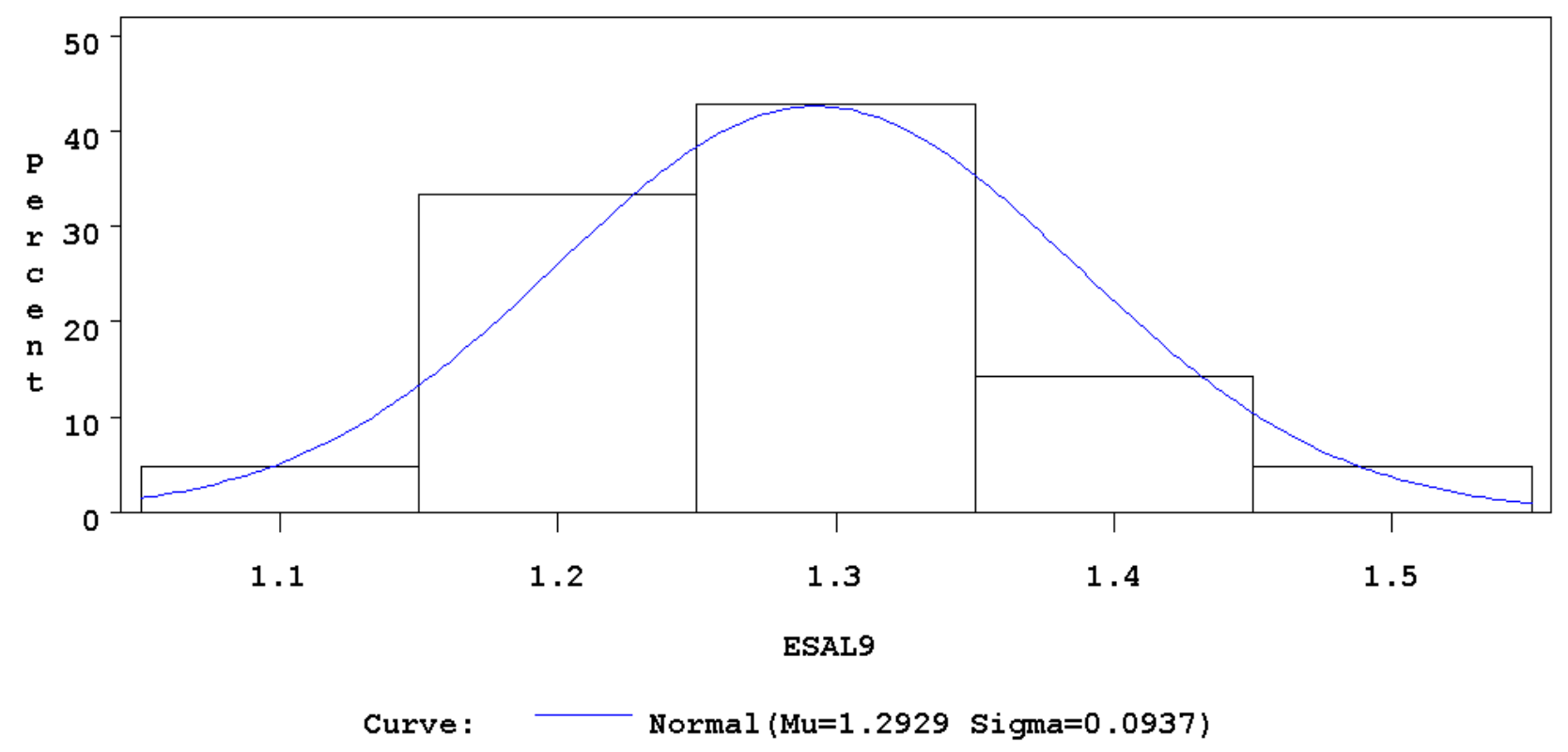


Figure 4. WIM station 4110, on I-65, May 1999, South Bound Travel Lane

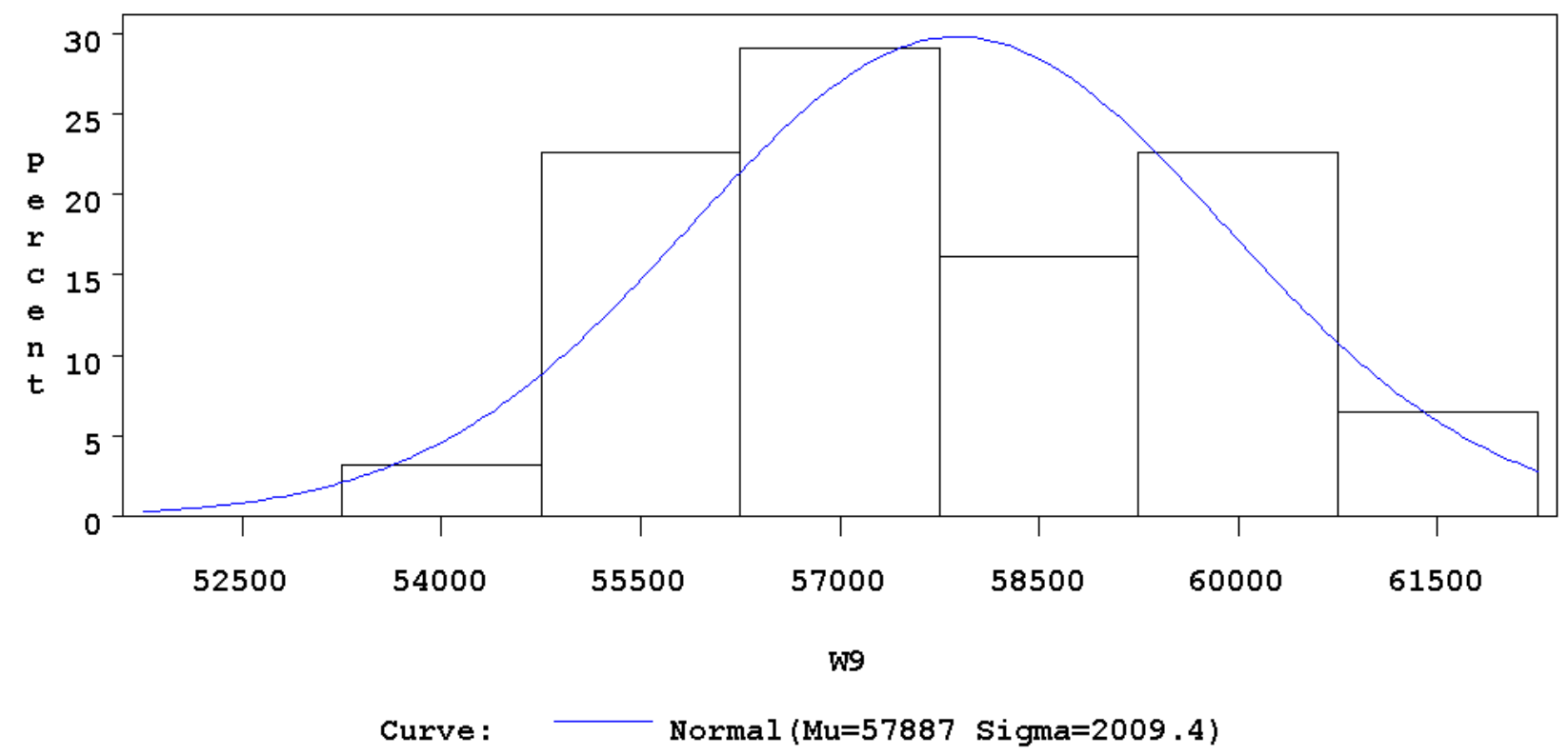

Where: W9 = Average daily GVW weight of Class 9 truck in lbs.

$\mathrm{Mu}=$ Average monthly GVW weight of Class 9 truck in lbs.

Note: $\quad M g=1000 \mathrm{Kg}=2.2075 \mathrm{Kips}=2207.5 \mathrm{lbs}$.

1bs. $=1 / 2207.5 \mathrm{Mg}$ 
Figure 5. WIM station 4250, on SR-2, June 1999, South Bound Travel Lane

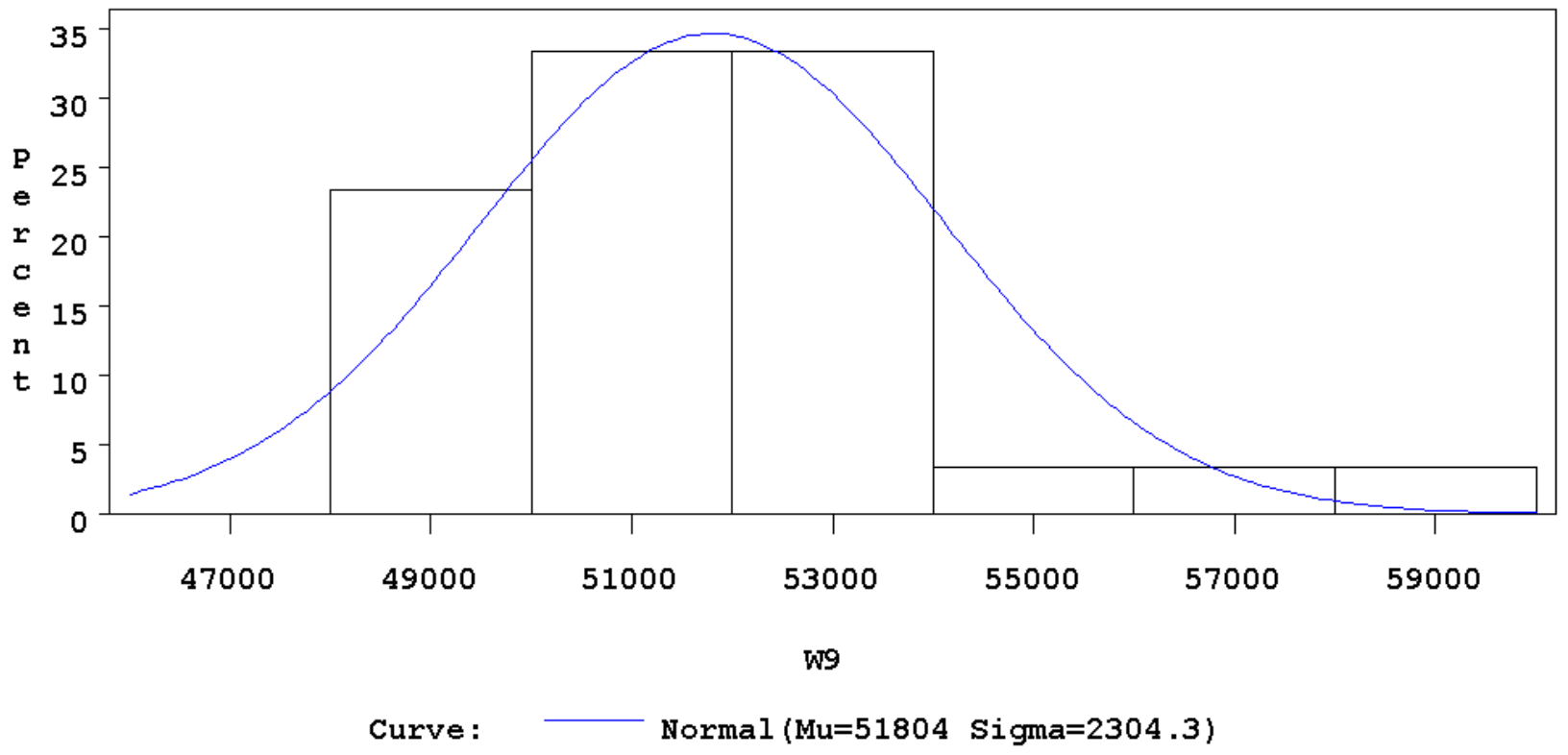


Figure 6. WIM station 5110, on I-70, October 1999, East Bound Travel Lane

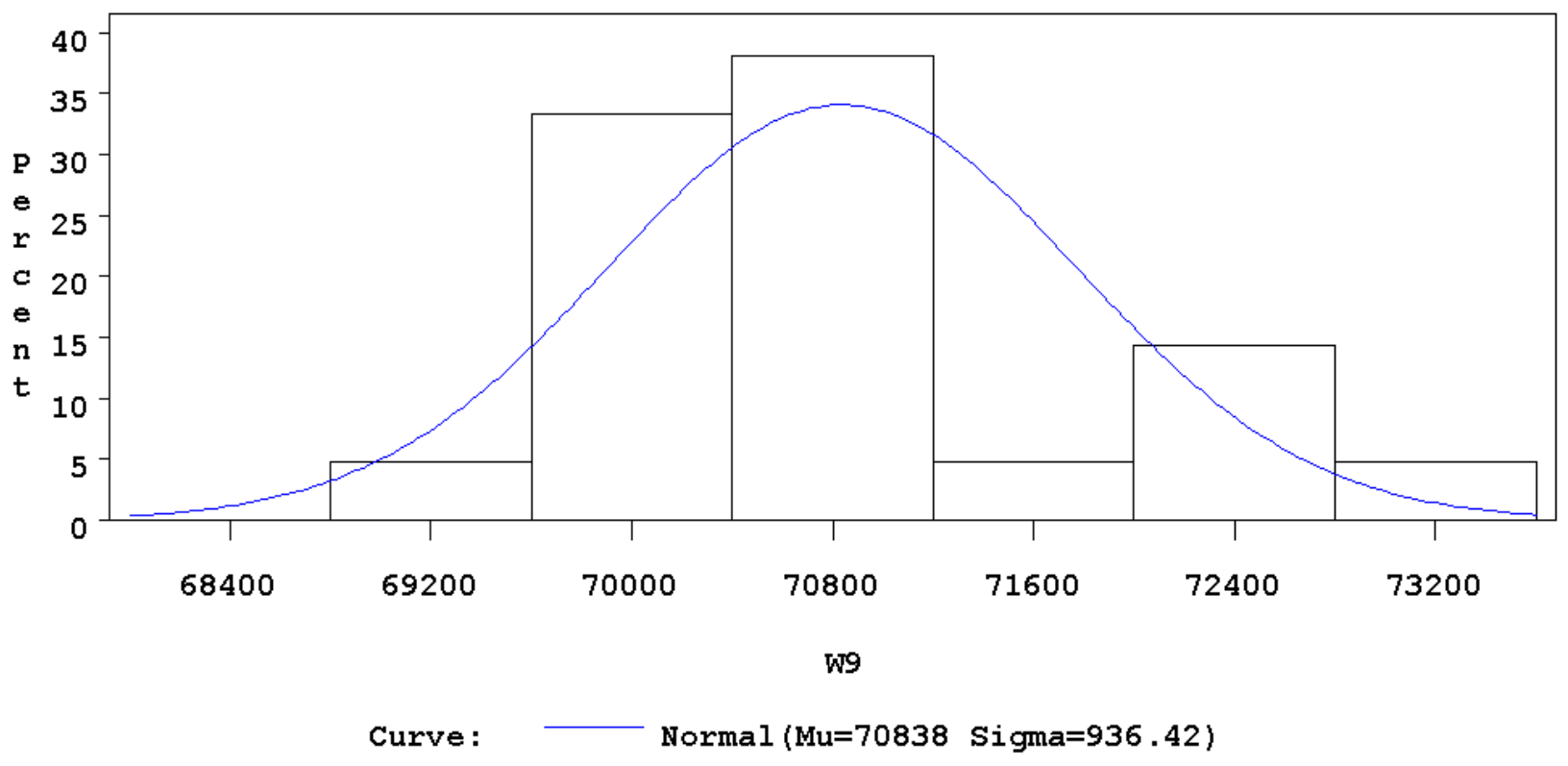

